\title{
AS CAPACIDADES DE LINGUAGEM EM GÊNERO ARTIGO DE OPINIÃO: UMA ANÁLISE TEXTUAL À LUZ DO INTERACIONISMO SOCIODISCURSIVO
}

\author{
Deymika de Carvalho Florêncio* \\ Paulo da Silva Lima**
}

\begin{abstract}
RESUMO: Neste estudo, objetivamos analisar como são mobilizadas as capacidades de linguagem (capacidades de ação, capacidades discursivas e capacidades linguístico-discursivas) para a construção de sentidos em gênero artigo de opinião. Selecionamos para a análise o artigo Aprendimentos Aterrados à Beira-Mar, um dos vencedores na Olimpíada de Língua Portuguesa Escrevendo o Futuro, 6 edição - 2019. Visamos compreender como o produtor do artigo analisado opera essas capacidades para estruturar o seu texto e construir sua argumentação. Para tanto, fundamentamo-nos no quadro teórico do Interacionismo Sociodiscursivo, destacando os estudos de Bronckart (2007) e Dolz e Schneuwly (2004), que defendem a produção e análise textual com base nas capacidades de linguagem, em Machado (2005), que auxilia na compreensão dessa teoria. Para o entendimento do gênero artigo de opinião, apoiamo-nos em Castellani e Barros (2018), Rodrigues (2005) e Uber (2008). Como resultados, constatamos que o produtor do artigo analisado desempenha com proficiência a ação de linguagem, demonstrando consciência quanto à situação e finalidade de comunicação. Apresenta conhecimentos quanto à estrutura do gênero artigo de opinião, apresentando uma situação polêmica, defendendo uma tese com argumentos e contra-argumentos, com uso de discurso teórico e sequências argumentativas. Ademais, apresenta mecanismos enunciativos e de textualização que contribuem para coesão e coerência textual.
\end{abstract}

PALAVRAS-CHAVE: Interacionismo sociodiscursivo; Capacidades de linguagem; Gênero artigo de opinião; Olimpíada de Língua Portuguesa Escrevendo o Futuro.

\section{Introdução}

Considerado de certa forma complexo, o artigo de opinião é um gênero textual opinativo, predominantemente argumentativo, característico da esfera jornalística-midiática, que tem como finalidade principal convencer o leitor sobre uma determinada ideia, influenciá-lo ou transformar seus valores a favor de uma posição assumida - tese, que se origina a partir de um assunto polêmico de ordem social (CASTELLANI; BARROS, 2018; RODRIGUES,

\footnotetext{
* Mestranda em Letras pela Universidade Federal do Maranhão (Ufma). Bolsista da Coordenação de Aperfeiçoamento de Pessoal de Nível Superior (Capes).

** Doutor em Letras pela Universidade Presbiteriana Mackenzie. Professor adjunto da Universidade Federal do Maranhão (Ufma). Professor Permanente do Programa de Pós-Graduação em Letras, Campus Bacabal (PGLB), da Ufma.
} 
2005). Desse modo, para produzir esse gênero é preciso que o indivíduo saiba mobilizar de maneira consciente as capacidades de linguagem necessárias para o seu desenvolvimento.

Conforme autores como Bronckart (2007) e Dolz e Schneuwly (2004), para a produção e constituição de um texto é preciso que um agente-produtor mobilize um conjunto de conhecimentos adquiridos nas suas experiências cognitivas e sociolinguageiras, conhecimentos esses tratados como capacidades de linguagem, são elas capacidades de ação, capacidades discursivas e capacidades linguístico-discursivas. Segundo Bronckart (2007), as capacidades de ação correspondem ao conjunto de operações que são a base de orientação para a ação de linguagem, compreende o contexto de produção (físico e sociossubjetivo), o conteúdo temático e as representações sobre o gênero. As capacidades discursivas são as que possibilitam a escolha da infraestrutura geral do texto, englobando o plano geral, os tipos de discurso e sua articulação e as sequências/tipologias textuais. E as capacidades linguístico-discursivas são as que envolvem os mecanismos de textualização e os mecanismos enunciativos.

Em vista disso, compreendendo a importância desta temática, este estudo tem como objetivo analisar como são mobilizadas as capacidades de linguagem (de ação, discursivas e linguístico-discursivas) para a construção de sentidos em gênero artigo de opinião. Para tanto, selecionamos para análise o artigo de opinião Aprendimentos Aterrados à Beira-Mar, um dos finalistas e vencedores na Olimpíada de Língua Portuguesa Escrevendo o Futuro (doravante OLPEF), $\sigma^{a}$ edição - 2019. Com base na proposta de análise textual do Interacionismo Sociodiscursivo, visamos compreender como o produtor do artigo opera essas três capacidades para produzir, estruturar, articular o seu texto e construir sua argumentação.

Nesse intuito, primeiramente analisaremos as operações relacionadas às capacidades de ação, focando o contexto de produção do artigo de opinião, com sua finalidade e conteúdo. Em seguida, as operações relacionadas às capacidades discursivas, em que investigaremos qual a planificação do texto, quais os tipos de discursos e sequências textuais predominam. E por último, as operações relacionadas às capacidades linguístico-discursivas, investigando como são estabelecidos os mecanismos de textualização e os mecanismos enunciativos. Essas operações de linguagem a serem analisadas são melhor esclarecidas no tópico da metodologia deste trabalho e sintetizadas em um quadro de análise que elaboramos nesse mesmo tópico.

Para o desenvolvimento desta investigação, nos fundamentamos no quadro teórico do Interacionismo Sociodiscursivo, destacando os estudos de Bronckart (2007) e Dolz e Schneuwly (2004), que defendem a produção e análise textual com base nas capacidades de linguagem, entendendo que elas configuram a estrutura semiótica do ato de comunicação, 
em Machado (2005), que auxilia na compreensão dessa teoria. E para a compreensão do gênero artigo de opinião, com suas características, apoiamo-nos em Castellani e Barros (2018), Rodrigues (2005) e Uber (2008).

Portanto, iniciamos o capítulo apresentado as formulações teóricas sobre o Interacionismo Sociodiscursivo e as capacidades de linguagem. Posteriormente, apresentamos as conceituações sobre o gênero artigo de opinião. Em seguida, expomos a metodologia da pesquisa, apresentando juntamente um quadro com as operações de linguagem específicas a serem analisadas no artigo de opinião. Logo após, realizamos a análise e por último, tecemos algumas considerações finais.

\section{O Interacionismo Sociodiscursivo e as capacidades de linguagem}

Para falarmos sobre o conceito de capacidades de linguagem se faz necessário sabermos antes sobre o quadro teórico a qual elas se inserem, que corresponde ao Interacionismo Sociodiscursivo (doravante ISD). O ISD é uma abordagem teórica e metodológica que se circunscreve no quadro epistemológico geral do Interacionismo Social, pode-se inferir que seja uma versão mais específica de continuação desse quadro.

Conforme Machado (2005), o ISD se contextualiza no quadro das disciplinas psicologia da linguagem e da didática de línguas que vêm sendo desenvolvidas pelo grupo de pesquisadores da Unidade de Didática de Línguas da Faculdade de Psicologia e Ciências da Educação da Universidade de Genebra, principalmente por Bronckart, Schneuwly e Dolz, que juntos buscaram constituir essa corrente.

Desse modo, esses autores têm em Vygotsky sua fonte de referência e uma abordagem marxista, dialética, dos fenômenos psicológicos, em defesa da reunificação da psicologia, à qual a concebem uma dimensão social e cujo objetivo central seria destacar as condições de emergência e funcionamento do pensamento consciente humano. Assim, trata-se de uma abordagem transdisciplinar que busca auxílio na Filosofia, Sociologia, Psicologia e Linguística, e busca se constituir como ciência do humano. De acordo com Bronckart (2006, p. 9-10), o ISD adere três aspectos gerais defendidos pelo interacionismo social:

\footnotetext{
1) O problema da construção do pensamento consciente humano deve ser tratado paralelamente ao da construção do mundo dos fatos sociais das obras culturais, sendo os processos de socialização e os processos de individuação (ou de formação das pessoas individuais) duas vertentes indissociáveis do mesmo desenvolvimento humano. 2) O questionamento das Ciências Humanas deve apoiar-se no admirável corpus da filosofia do espírito (de Aristóteles e Marx) e deve, simultaneamente, considerar os problemas de intervenção prática (e principalmente os de intervenção no campo escolar). 3) Convém contestar a divisão dessas Ciências em múltiplas disciplinas e subdisciplinas [...] tendo em vista que os problemas centrais de uma ciência do humano envolvem, de um lado, as relações de interdependência que se instauram e se desenvolvem entre os aspectos fisiológicos, que
} 
cognitivos, sociais, culturais, linguísticos etc. do funcionamento humano e, de outro, os processos evolutivos e históricos por meio dos quais essas diferentes dimensões se geraram e se construíram. (BRONCKART, 2006, p. 9-10)

Partindo dessas premissas, o ISD visa demonstrar que as práticas de linguagem são os instrumentos de desenvolvimento do pensamento consciente humano, não apenas em termos de compreensão, mas em termos de desenvolvimento de capacidades de agir e de formação identitária da pessoa, ou seja, as capacidades de pensamento são marcadas não só por aspectos puramente cognitivos, mas fundamentalmente pelo sociocultural e pela linguagem.

Nesse contexto, esses estudiosos entendem que o trabalho com os gêneros textuais, como práticas de linguagem, é a principal mediação no processo de desenvolvimento e formação do indivíduo, e destacam que a produção e constituição de um texto é resultado de operações de linguagem, as quais são compiladas em capacidades de linguagem.

Desse modo, para a produção de um texto, um agente-produtor deve mobilizar um conjunto de conhecimentos adquiridos nas suas experiências cognitivas e sociolinguageiras. Esses conhecimentos são tratados como capacidades de linguagem e subdividem-se em três: a capacidade de ação, em que o produtor adapta-se às características do contexto e do referente; a capacidade discursiva em que mobiliza modelos discursivos e a capacidade linguístico-discursiva em que domina as operações psicolinguísticas e as unidades linguísticas (DOLZ, SCHNEUWLY, 2004, p.44).

Conforme Bronckart (2007), a capacidade de ação corresponde ao conjunto de operações que são a base de orientação para a ação de linguagem, ela que vai direcionar todo o percurso de conteúdo da produção textual, sendo decisiva para a realização de todas as demais operações posteriores. Em outras palavras, ela que determinará toda a organização e estruturação do texto. Compreende o contexto de produção (físico e sociossubjetivo), o conteúdo temático e as representações sobre o gênero.

Para Machado (2005), nesse plano destacam-se: os conteúdos que serão verbalizados; o espaço-tempo em que o emissor e o receptor se situam; o produtor e o destinatário no seu aspecto físico; o lugar social no qual se realiza a interação e no qual vai circular o texto; os papéis sociais desempenhados pelo emissor e receptor e os efeitos que o produtor quer produzir no destinatário, ou seja, se quer informar, convencer, ordenar, solicitar, divertir, entre outros.

Como já mencionado, além da capacidade de ação, outras capacidades necessárias para ação de linguagem são as capacidades discursivas e linguística-discursivas, que de acordo com Bronckart (2007), correspondem à arquitetura interna do texto, elas se decompõem em três planos de organização: a infraestrutura geral do texto, os mecanismos de textualização e os mecanismos 
enunciativos. Essas três divisões são chamadas pelo o autor supracitado de folhado textual, o qual possui valor hierárquico e serve como uma base metodológica para se analisar o processo de organização do texto, tanto no aspecto de elaboração quanto de construção de sentido.

Desse modo, a capacidade discursiva é a que possibilita a escolha da infraestrutura geral do texto, considerada a camada mais profunda da arquitetura textual (BRONCKART, 2007, p. 120), que engloba o plano geral, os tipos de discurso e sua articulação e as sequências/tipologias textuais.

O plano geral refere-se ao modo como é organizado o conteúdo temático, apresentase explicitamente no processo da leitura. Já os tipos de discurso correspondem aos diferentes segmentos que o texto apresenta, podem ser de narração, discurso teórico, discurso interativo e relato interativo. Esses tipos de segmentos podem se mesclar dentro do texto, essa articulação segundo Bronckart (2007), pode acontecer ou por encaixamento ou por fusão. E as sequências/tipologias textuais são as formas possíveis de planificação linguísticas. Distribuem-se em seis tipos: dialogal, descritiva, narrativa, injuntiva, explicativa, argumentativa. Expliquemos aqui a argumentativa, que é a predominante no gênero artigo de opinião. Conforme Machado (2005, p. 246), a sequência argumentativa pretende "converter o destinatário da validade de posicionamento do produtor diante de um objeto de discurso visto como contestável (pelo produtor e/ou pelo destinatário)". Possui as fases de estabelecimento de premissas, suporte argumentativo, contra-argumentação e conclusão.

Por último, tem-se a capacidade linguística-discursiva que envolve os mecanismos de textualização e os mecanismos enunciativos. Os mecanismos de textualização contribuem para coerência temática e distribuem-se em três tipos de mecanismos: o primeiro tipo, são os de conexão, que são realizados por meio de organizadores textuais que demarcam as transições entre os tipos de discursos, entre fases de uma sequência ou articulação entre fases sintáticas; o segundo tipo, são os de coesão nominal que podem ter a função de introdução, ao demarcar no texto a inserção de uma nova unidade de significação, dando origem a uma cadeia anafórica e também podem exercer a função de retomada, ao reformular uma unidade antecedente no texto. E o terceiro tipo, são os de coesão verbal, que ajudam a manter as "relações de continuidade, descontinuidade e/ ou de oposição existentes entre os elementos de significação expressos pelos sintagmas verbais” (BRONCKART, p.273).

Quanto aos mecanismos enunciativos (ibid., p. 319), esses contribuem para regulação da coerência pragmática (interativa) do texto, para o esclarecimento dos posicionamentos enunciativos, ou seja, das vozes (sociais, do autor, dos personagens) que se enunciam e que 
traduzem avaliações (julgamentos, opiniões, sentimentos) sobre o conteúdo temático, avaliações essas denominadas modalizações.

As modalizações, segundo Bronckart (2007, p. 330), são de quatro modos: as lógicas, que expressam valor de verdade das proposições enunciadas, apresentadas como certas, possíveis, prováveis; as deônticas, em que os enunciados são avaliados à luz dos valores sociais, como socialmente permitidos, proibidos, necessários; as apreciativas, que refletem julgamentos mais subjetivos, apresentando fatos enunciados como bons, maus, estranhos; e as pragmáticas em que o enunciador transfere a um agente uma responsabilidade de ação.

É importante ressaltar que embora possa haver essa subdivisão entre as capacidades para nível de compreensão, elas são interdependentes, no texto não se dão de forma separada. Desse modo, de posse sobre os conhecimentos relacionados às capacidades de linguagem, passemos a conhecer sobre o gênero artigo de opinião.

\section{O gênero artigo de opinião}

Considerado de certa forma complexo, o artigo de opinião é um gênero textual opinativo, característico da esfera jornalística-midiática, que tem predominância da argumentação, sua finalidade principal é convencer o leitor sobre uma determinada ideia, influenciá-lo ou transformar seus valores a favor de uma posição assumida - tese, que se origina a partir de assunto polêmico de ordem social (CASTELLANI; BARROS, 2018; RODRIGUES, 2005; UBER, 2008).

Esse gênero tem por característica opinar sobre uma temática atual, geralmente polêmica, que circula pela sociedade através da mídia, como afirma Uber (2008, p. 9) “um artigo de opinião discute questões que podem incidir sobre variados temas: sociais, políticos, científicos e culturais, de interesse geral e atual, que afetam direta ou indiretamente um número de pessoas, a partir de um fato ocorrido e noticiado". Assim, para fundamentar a sua ideia sobre a questão polêmica, o articulista se utiliza de argumentos e contra-argumentos para sustentar, refutar ou negociar sentidos sobre a questão controversa apresentada.

Pertencente ao campo jornalístico-midiático, o gênero escrito em questão, frequentemente é publicado em jornais e revistas impressos e digitais, além de blogs, sites e portais de notícias e é sempre assinado. Porém, conforme Castellani e Barros (2018), o artigo não precisa ser especificamente produzido por um jornalista, em muitos jornais e revistas o artigo de opinião é de responsabilidade de um articulista contratado ou convidado pela linha editorial ou mesmo por seus leitores.

Para Castellani e Barros (2018), a questão polêmica que direciona o que será discutido no artigo é uma "pergunta-chave" que inquieta o leitor/articulista e o motiva a escrever. 
Assim ao escrever, ele assume uma posição (tese) que pode ser contra ou a favor dessa questão polêmica. As autoras destacam que os posicionamentos dos produtores dos artigos podem ocorrer de forma mais explícita ou implícita, dependendo de suas intenções.

Contribuindo para compreensão desse gênero, podemos destacar a conceituação de Rodrigues (2005), que enfatiza que o artigo tem um caráter dialógico, pois se constrói a partir de uma dupla orientação, tanto como resposta aos já ditos, quanto busca causar uma resposta ao seu interlocutor.

\footnotetext{
O gênero artigo mostra com a textualização do acontecimento motivador, a sua dupla orientação: constitui como uma reação-resposta a esses enunciados da atualidade (o já dito) e busca a reação-resposta ativa do seu interlocutor.

(...) A orientação para os enunciados já ditos e sua incorporação no artigo realizase na verdade, em razão do interlocutor, pois é em função dele que se constrói o discurso. A orientação para o já dito, em parte, constitui-se como uma estratégia discursiva-argumentativa, pois mediante a relação dialógica do artigo com esses enunciados o articulista vai construindo o seu objeto de discurso, tecendo o seu ponto de vista, orientado para uma reação resposta ativa ao seu destinatário. O interlocutor (leitor) é a "medida" dessa orientação diante do já dito. (RODRIGUES, 2005, p. 173, 178)
}

Dessa forma, podemos entender que na produção do artigo de opinião o interlocutor tem, pois, um papel crucial, na verdade o que é dito no artigo é dito em função dele. Além disso, esse olhar para o que já foi falado torna-se uma estratégia discursiva-argumentativa para o articulista, visto que a partir desses enunciados anteriores é que o articulista vai construir o seu discurso, já pensando na reação que vai causar em seu interlocutor.

Passando ao aspecto estrutural do artigo de opinião, Castellani e Barros (2018) esclarecem que o artigo de opinião é um gênero do expor-interativo, predominando o discurso teórico. Geralmente é escrito em primeira pessoa do singular ou do plural, estruturado pela sequência argumentativa, já que o objetivo, como já mencionado, geralmente é convencer o leitor sobre determinada ideia. Porém, evidentemente, apresenta outras sequências, como a descritiva, por exemplo, no momento em que o autor introduz e descreve sobre a temática que irá abordar.

Conforme as autoras, esse gênero apresenta um título, que, em alguns casos, pode ser a própria questão polêmica do artigo, ou então uma frase que retrate a polêmica que será abordada de uma maneira geral, o que já pode apontar a posição do autor.

No desenvolver do artigo de opinião, discursivamente, o autor apresenta argumentos e contra-argumentos para sustentar sua tese. Esses argumentos se apoiam em dados de pesquisa, de reportagens, levantamentos, entre outros (ibid. p. 207). Geralmente a problemática é trazida logo nos primeiros parágrafos, e normalmente o autor já se posiciona. Já na conclusão, o autor reforça seu posicionamento, ou traz uma nova questão que possa suscitar uma 
nova discussão. Assim pode-se dizer que o artigo apresenta uma introdução (com a polêmica ou tomada de posição - tese), desenvolvimento (justificação, com argumentos e contra-argumentos) e uma conclusão (reforço de posição ou introdução que suscite uma nova discussão).

O tempo verbal predominante no artigo de opinião é o presente do indicativo, pois é nessa temporalidade do aqui e agora que o autor argumenta, critica, se posiciona, também pode estar com valor atemporal. No entanto, podem aparecer verbos que indicam tempo passado e futuro.

Para manter à coerência temática e a coesão do artigo, o autor faz uso de retomadas textuais, a partir anáforas nominais e pronominais, garantindo o processo de referenciação. Também se utiliza de articuladores textuais tais como (mas, porém, conforme, portanto etc), modalizadores como (é preciso, é evidente), metaformulativos: (mais precisamente, em suma, quanto a, em relação a etc.) faz uso de dêiticos como: (agora, hoje, neste momento, este, esse, aquele, aquilo, daqui por diante) e entre outras formas de articulação (CASTELLANI; BARROS (2018); RODRIGUES, 2005).

Além disso, compreende-se que, no gênero artigo de opinião, se faz uso de uma linguagem mais formal, com expressões mais específicas típicas do meio em que o autor se inscreve. No entanto, eventualmente pode-se utilizar de uma linguagem mais coloquial, já que o autor quer manter diálogo com o leitor.

No gênero em questão, o autor ainda faz uso de alguns recursos para dar tonicidade ao seu discurso, como sinal de interrogação, para fazer perguntas retóricas, críticas; aspas, itálico, caixa alta, para destacar expressões; metáforas, para ironizar. No que se refere às vozes enunciativas, a voz que predomina no gênero artigo é a voz do autor, no entanto, ele incorpora no texto outras vozes, seja para validá-las, em concordância com seu ponto de vista, como um "movimento dialógico de assimilação", seja para apagá-las, desqualificá-las, em que o autor se distancia, se opõe, como um "movimento de dialógico de distanciamento" (RODRIGUES, 2005, p. 174).

Ainda com relação às outras vozes trazidas nesse gênero, conforme a autora supracitada, resta saber que no artigo de opinião, há predominância do discurso relatado indireto, a estudiosa explica que isso ocorre porque a finalidade discursiva desse gênero, se orienta mais para a análise e comentário do discurso do outro "do que pela sua "expressão" propriamente dita" (ibid. 177).

Existem ainda várias outras características presentes no gênero artigo de opinião, que por questão de espaço, nos foi conveniente elencar as supracitadas como sendo as predominantes. Essas características servirão de base para nossa análise como veremos adiante. 


\section{Metodologia}

Selecionamos para a análise o artigo de opinião Aprendimentos Aterrados à Beira-Mar, que foi um dos finalistas e vencedores na OLPEF, $6^{a}$ edição - 2019. O artigo foi escrito por uma estudante do $3^{\circ}$ ano do Ensino Médio de uma escola pública da cidade de Fortaleza, no Ceará. Sob a temática "O lugar onde vivo" proposta pela OLPEF, o artigo supracitado aborda sobre problemas relacionados ao projeto de requalificação da Avenida Beira-Mar da cidade Fortaleza - CE. Tal produção foi retirada da coletânea (virtual) de textos finalistas $6^{a}$ edição - 2019 da OLPEF, disponível no site do Programa Escrevendo o Futuro.

A OLPEF é um concurso de produção de textos para estudantes de escolas públicas de todo o país. Tem iniciativa do Ministério da Educação e do Itaú Social, com coordenação técnica do Centro de Estudos e Pesquisas em Educação, Cultura e Ação Comunitária (CENPEC), integra as ações desenvolvidas pelo Programa Escrevendo o Futuro. O concurso atinge as séries do Ensino fundamental e Médio, propondo que professores orientem estudantes a escreverem textos em categorias Poema ( $5^{\circ}$ ano EF), Memórias Literárias ( $6^{\circ}$ e $7^{\circ}$ anos EF), Crônica ( $8^{\circ}$ e $9^{\circ}$ anos EF), Artigo de opinião ( $3^{\circ}$ ano EM) e Documentário ( $1^{\circ}$ e $2^{\circ}$ anos EM). Acontece ao longo do ano da edição, em que as produções passam por seleções de várias etapas, sendo a Escolar, Municipal e Estadual até chegar na etapa Nacional em que professores e alunos participam de encontros semifinalistas e finalistas, com direito à premiações e depois publicação dos textos finalistas.

$\mathrm{Na}$ edição de 2019, teve a participação de 85.908 professores, de 42.086 escolas de todo o país. Dentre 569 estudantes semifinalistas e seus professores (medalha de bronze), 173 foram selecionados como finalistas (medalha de prata) e 28 foram vencedores (medalha de ouro). O artigo em questão analisado pertence a um desses vencedores, cuja sua escolha se deu aleatoriamente.

Dessa forma, considerando as características do gênero artigo de opinião elencadas no tópico anterior e as colocações do ISD, é que analisaremos as três capacidades de linguagem (capacidades de ação, capacidades discursivas e capacidades linguístico-discursivas) mobilizadas no artigo em questão. Dessa forma, primeiramente analisaremos as capacidades de ação, em que focaremos o contexto (físico e sociossubjetivo) de produção do artigo, o papel da produtora (articulista), do público leitor e a finalidade de produção, ou seja, os efeitos que o produtor quer produzir no destinatário, que no artigo geralmente é convencer, defender, influenciar valores a favor de uma tese e o conteúdo temático.

Em seguida, analisaremos as capacidades discursivas, em que investigaremos a planificação do texto, se apresenta a seguinte estrutura: uma introdução (com a polêmica ou tomada 
de posição - tese), desenvolvimento (justificação, com argumentos e contra-argumentos) e uma conclusão (reforço de posição ou introdução que suscite uma nova discussão), quais os tipos de discurso (se predomina o discurso do mundo do EXPOR, discurso teórico), se predomina a sequência argumentativa, entre outros.

E por último, analisaremos as capacidades linguístico-discursivas, em que analisaremos se são estabelecidos os mecanismos de textualização e enunciativos, ou seja, se são estabelecidos mecanismos de coesão verbal e nominal, uso de articuladores textuais, dêiticos, modalizadores, presença de outras vozes enunciativas, recursos de entonação, entre outros elementos. Para melhor compreensão de como será a análise, elaboramos um quadro sintetizando as três capacidades de linguagem, com seus elementos e operações que desejamos identificar e analisar no artigo de opinião:

Quadro 1 - Capacidades de linguagem para a análise do gênero artigo de opinião

\section{CAPACIDADES DE AÇÃO}

Lugar físico e social de produção do artigo de opinião

Agente-produtor (articulista)

Público leitor

Finalidade de produção/ tematização: convencer, influenciar ou transformar valores do leitor a favor de uma posição assumida - tese

Conteúdo temático

\section{CAPACIDADES DISCURSIVAS}

Planificação / organização temática

Estrutura composicional: título, introdução (com a polêmica ou tomada de posição - tese), desenvolvimento (justificação, com argumentos e contra-argumentos) e uma conclusão (reforço de posição ou introdução que suscite uma nova discussão)

Pertence ao mundo do Expor, predomínio de discurso teórico;

Predominância de sequência argumentativa

Discurso em $1^{a}$ pessoa do singular e plural.

\section{CAPACIDADES LINGUÍSTICO-DISCURSIVAS}

Coesão nominal com retomadas textuais/ processos de referenciação anafóricas nominais e pronominais

Coesão verbal

Tempos verbais no presente

Uso de articuladores textuais; dêiticos

Recursos para dar tonicidade

Mecanismo enunciativos: voz predominante do produtor/ incorporação de outras vozes

Presença de discurso indireto (predominante) e discurso direto 
Uso de modalizações características da argumentação como: é preciso, constata-se, é evidente

Fonte: Elaborado pelos autores.

Portanto, de posse desses conhecimentos, podemos seguir com a análise.

\section{Análise do artigo de opinião Aprendimentos Aterrados à Beira-Mar}

Neste tópico, iremos analisar primeiramente a mobilização das capacidades de ação, em seguida, das capacidades discursivas e por último, das capacidades linguístico-discursivas, seguindo o Quadro $1 \mathrm{com}$ as operações e características específicas para análise do gênero artigo de opinião, apresentado no tópico anterior. Segue a seguir o texto a ser analisado.

Quadro 2 - Artigo de opinião Aprendimentos Aterrados à Beira-Mar

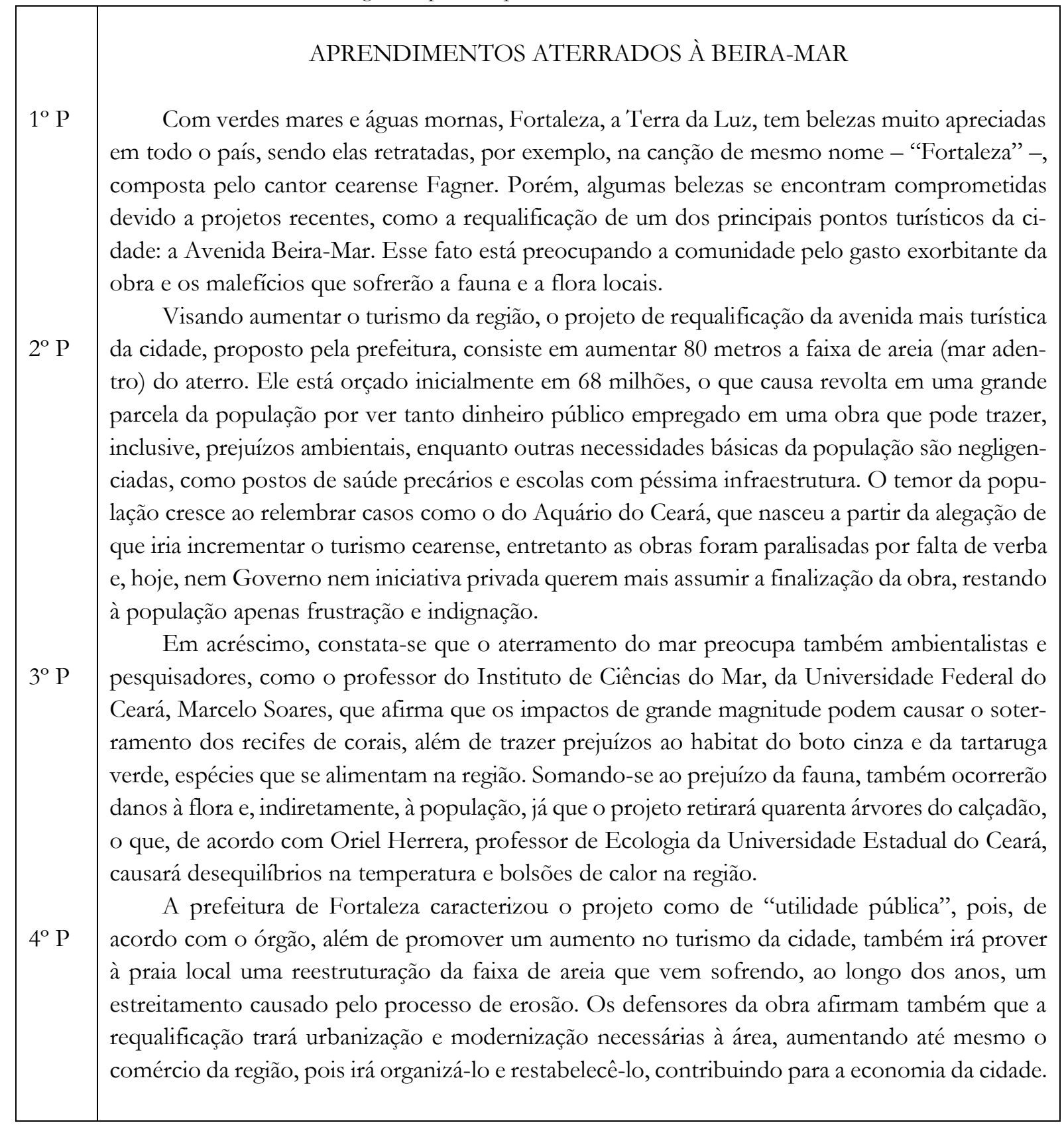




\begin{tabular}{|c|c|c|}
\hline $5^{\circ} \mathrm{P}$ & $\begin{array}{r}\text { Em contrapartida, acredito que tal avanço na urbanização de um setor belo por si desfoca } \\
\text { a prefeitura de problemas mais que afetam a população, exercendo, assim, uma política apelidada } \\
\text { como "pra turista ver". Enquanto isso, áreas periféricas da cidade sofrem pelo descaso em vários } \\
\text { espaços públicos, como escolas e postos de saúde, além da ausência de saneamento básico na } \\
\text { maioria das comunidades que se encontram mais distantes da região considerada "nobre", como, } \\
\text { por exemplo, o bairro Jangurussu, que convive com a poluição e esgotos expostos, prejudicando } \\
\text { a saúde e o bem-estar da população. } \\
\text { Concordo, portanto, com a doutora em Ciências Marinhas, Liana Queiroz, quando ela } \\
\text { o P }\end{array}$ & $\begin{array}{l}\text { afirma que "é imensurável a real magnitude do impacto [causado pelo aterro] em toda biodiver- } \\
\text { sidade [...]", uma vez que essas consequências negativas são certas e as atitudes para revertê-las } \\
\text { nem sempre se concretizam. Além das implicações ecológicas, acresça-se que a natureza tem } \\
\text { muito a nos ensinar, como afirma o poeta Manoel de Barros, em seu poema "Aprendimentos", } \\
\text { ao dizer que "não tinha as certezas científicas, mas que aprendera coisas di-menor com a natu- } \\
\text { reza", coisas estas que não dizem respeito a interesses econômicos, mas à teia da vida. } \\
\text { Para um litoral bonito, antes de tudo, deve-se preservá-lo, pois, talvez assim, os verdes } \\
\text { mares do Mucuripe e a Avenida Beira-Mar possam encher os olhos dos habitantes e turistas de } \\
\text { Fortaleza pela beleza natural, e não artificial, de suas praias. }\end{array}$ \\
$7^{\circ} \mathrm{P}$
\end{tabular}

Fonte: OLIMPÍADA, 2019.

Nesse artigo de opinião, no que se refere às capacidades de ação, que segundo Bronckart (2007), compreendem o contexto de produção, o conteúdo temático e as representações sobre o gênero, a princípio, pode-se se perceber que a agente-produtora do texto consegue desempenhar de forma consciente a ação linguageira que é, como estudante, produzir um artigo de opinião que corresponda a temática "O lugar onde vivo" proposta pela OLPEF.

$\mathrm{O}$ artigo foi produzido por Rúbia Ellen Campelo Costa, aluna do $3^{\circ}$ ano do ensino médio da escola EEM Governador Adauto Bezerra, da cidade Fortaleza no estado do Ceará, que como candidata participou juntamente de sua professora orientadora Suziane Brasil Coelho, do concurso de produção de textos da $6^{\text {a }}$ edição da OLPEF, 2019, na categoria artigo de opinião. A produção do texto ocorreu em cerca de 3 meses, onde passou por várias etapas até chegar sua configuração final.

Primeiramente, o texto passou pela etapa de produção textual que é feita em sala de aula pelo professor inscrito no concurso, onde ocorreu a primeira produção dos alunos em que o leitor inicial é o professor orientador que ajuda na seleção do texto que representará sua escola. Após o texto ser um dos selecionados pela escola, ele passou por diferentes leitores, no qual participou de uma seleção municipal e estadual, com suas respectivas secretarias de educação, para chegar como texto finalista nacional, com direito à premiações e para ser publicado na coletânea do ano que ocorreu o concurso e no site deste, assim, atingindo leitores de todo país. 
Desse modo, a aluna-produtora, com o apoio de sua professora orientadora, ao produzir este artigo assume um papel social bastante importante, pois além de aprender sobre o gênero, como cidadã opina sobre as mazelas de sua cidade, podendo com seus posicionamentos ajudar resolver os problemas os quais destaca e como escritora finalista, representar positivamente a sua escola, sua cidade, seu estado em um concurso de nível nacional tão relevante como esse.

No que tange ao conteúdo temático, como já dito, o texto atende à temática proposta pelo concurso "O lugar onde vivo", assim sob o título Aprendimentos Aterrados à Beira-Mar, em seu artigo, a aluna propõe falar sobre os projetos de requalificação turísticas, em sua cidade de Fortaleza, em especial o da requalificação da Avenida Beira-Mar que tem preocupado a população por conta dos elevados gastos da obra e por poder causar problemas ambientais, trazendo malefícios a fauna e a flora locais.

Quanto ao plano geral, que é como está organizado o conteúdo temático (BRONCKART, 2007, p. 120) no artigo, é apresentado um título que situa o leitor sobre a temática que será abordada e uma discussão em sete parágrafos, que neles podemos observar uma introdução (com a polêmica e uma tese), um desenvolvimento com (argumentos e contraargumentos) e uma conclusão (com reforço da posição), seguindo a planificação do gênero como inserem Castellani e Barros (2018).

No primeiro parágrafo a aluna introduz o seu texto, contextualizando sobre a sua cidade de Fortaleza, descrevendo-a como um lugar de verdes mares e águas mornas, conhecida como Terra da Luz e que tem belezas muito apreciadas em todo país. Porém, apresentando a tese do texto, enfatiza em seguida que algumas dessas belezas da cidade se encontram comprometidas por causa de projetos de requalificação turística, como o da requalificação da Avenida Beira-Mar, cujo projeto tem preocupado a comunidade por conta dos elevados gastos da obra e por poder trazer malefícios à fauna e à flora locais.

Dando prosseguimento, nos próximos parágrafos a aluna-articulista traz os argumentos e contra-argumentos para sustentar sua posição (UBER, 2008). No segundo parágrafo ela desenvolve o que foi dito na introdução, trazendo mais informações sobre o projeto de requalificação da avenida, esclarecendo que o projeto “visando aumentar o turismo da região" [...] consiste aumentar 80 metros a faixa de areia (mar adentro) do aterro" e está orçado inicialmente em 68 milhões de reais, sendo que esse orçamento revolta parte da população, por ver tanto dinheiro público empregado numa obra que pode até trazer prejuízos ambientais, enquanto outras necessidades básicas da população são negligenciadas. Ainda nesse segundo parágrafo é incrementado que a preocupação da população aumenta por relembrar de uma obra 
semelhante, a do Aquário do Ceará, que até então se encontrava paralisada sob alegação de falta de verba.

No terceiro parágrafo, o artigo discute sobre os problemas ambientais que a obra pode causar, trazendo para o texto a fala de ambientalistas e pesquisadores, como Marcelo Soares, que argumenta que os impactos de grande magnitude podem causar o soterramento dos recifes de corais, além de trazer prejuízos ao habitat de alguns animais. E também argumenta que trará prejuízo à flora e consequentemente à população, já que o projeto visa retirar algumas árvores, o que pode causar, segundo Horiel Herrera, desequilíbrios na temperatura e bolsões de calor na região.

A autora do artigo já traz um contra-argumento no quarto parágrafo, trazendo a posição da prefeitura em relação ao projeto, que o caracteriza como de "utilidade pública", que trará urbanização e promoverá o aumento do turismo e da economia da cidade. No entanto, contrapõe a posição da prefeitura inserida no parágrafo anterior, argumentando que o avanço na urbanização de um setor que já é belo desfoca a prefeitura de outros problemas que afetam a população, praticando assim, uma política apelidada como "pra turista ver". Em seguida, é discorrido sobre esses outros problemas que afetam a cidade.

No sexto parágrafo, o texto inicia sua posição conclusiva, trazendo uma outra voz para ratificar seu posicionamento, menciona que concorda com "a doutora em Ciências Marinhas, Liana Queiroz, quando afirma que "é imensurável a real magnitude do impacto [causado pelo aterro] em toda biodiversidade [...] uma vez que essas consequências negativas são certas e as atitudes para revertê-las nem sempre se concretizam”. Ademais, para finalizar esse parágrafo, é trazido o trecho do poema "Aprendimentos" (o qual inspira o título do artigo) do poeta Manoel de Barros, construindo a ideia de que a natureza tem muito a nos ensinar.

Por último, o artigo se finaliza com o sétimo parágrafo, em que a produtora insere uma solução para a problemática, e ratifica o seu posicionamento construído ao longo do texto em relação à temática, enfatizando que para se ter um litoral bonito, se faz necessário, antes de tudo preservá-lo, "talvez assim, os verdes mares do Mucuripe e a Avenida Beira-Mar possam encher os olhos dos habitantes e turistas de Fortaleza pela beleza natural, e não artificial, de suas praias".

Ainda sobre a organização temática, o artigo se configura do mundo do EXPOR, desenvolvendo um discurso teórico, com frases declarativas, com ausência de pessoa, com valor de autonomia, de verdade, típico do discurso teórico (BRONCKART, 2007), como em "Com verdes mares e águas mornas, Fortaleza, a Terra da Lu₹, tem belezas muito apreciadas em todo o país" $\left(1^{\circ} \mathrm{P}\right)$ / "Em acréscimo, constata-se que o aterramento do mar preocupa também ambientalistas e pesquisadores" ( $\left.3^{\circ} \mathrm{P}\right)$. No entanto, insere-se também o discurso interativo (CASTELLANI e 
BARROS, 2018) em que a produtora, de forma menos regular, fala em $1^{\circ}$ pessoa do singular e do plural como forma de manter uma relação mais direta com o leitor, de inclui-lo e incluirse: "Em contrapartida, acredito que tal avanço na urbanização" (5 P) / "acresşa-se que a natureza tem muito a nos ensinar" (6 $\left.6^{\circ} \mathrm{P}\right)$.

No artigo, há predominância de sequências argumentativas, como já destacado, apresenta um posicionamento, uma tese referente à temática logo no primeiro parágrafo, e no decorrer do texto, apresenta-se argumentos e contra-argumentos que sustentam seus discursos, até chegar em sua posição final na conclusão. Podemos observar essa sequenciação na própria introdução, em que argumenta-se que a cidade Fortaleza tem "belezas muito apreciadas em todo o país [...] porém, algumas belezas se encontram comprometidas devido a projetos recentes, como a requalificação de um dos principais pontos turísticos da cidade: a Avenida Beira-Mar' (1 P). Dessa forma, o artigo apresenta seu problema, a polêmica e sua causa e mais a frente ainda apresenta os efeitos, os problemas principais que surgem por causa da obra, que é preocupação da comunidade pelo gasto exorbitante da obra e os malefícios que sofrerão a fauna e a flora locais, fato esse que completa a primeira colocação.

Com o intuito de informar, convencer, influenciar o leitor, a aluna constrói a argumentação de seu texto, mesclando os parágrafos com os argumentos contrários e a favor de sua posição, trazendo as vozes que circunscrevem à temática, como a voz dos encarregados pela obra, que é a prefeitura, a voz dos que temem a construção que é da população, dos ambientalistas pesquisadores, professores e sua própria voz. Essa sequenciação argumentativa com posições e vozes pode ser vista, por exemplo, no segundo parágrafo, quando é explicado na forma de discurso indireto, o que é a obra e seu objetivo, com base no que a prefeitura deve ter informado: "visando aumentar o turismo da região, o projeto de requalificação da avenida mais turística da cidade, proposto pela prefeitura, consiste em aumentar 80 metros a faixa de areia (mar adentro) do aterro. Ele está orçado inicialmente em 68 milhões".

No que concerne às capacidades linguístico-discursivas, que segundo Bronckart (2007), envolvem os mecanismos de textualização e enunciativos, podemos constatar que o texto apresenta elementos de coesão nominal, em que se faz uso de anáforas nominais e pronominais garantindo o processo de referenciação. Por exemplo, quando o termo "belezas" é substituído por "elas": "tem belezas muito apreciadas em todo o país, sendo elas retratadas [...]" $\left(l^{\circ} \mathrm{P}\right)$. Quando "projeto" é substituído por "obra”; "população” por "comunidade”, "prejuízo" por "danos". Também encontramos referenciação dêitica no uso de "esse": algumas belezas se encontram comprometidas devido a projetos recentes, como a requalificação de um dos principais pontos turísticos da cidade: a Avenida Beira-Mar. Esse fato está preocupando a comunidade [...] (1º $\mathrm{P})$. 
Estabelece-se ainda coesão entre os sintagmas verbais, e principalmente, ao longos do parágrafos, faz-se uso de tempos verbais no presente, que é característico do gênero, como podemos observar no primeiro parágrafo: "algumas belezas se encontram comprometidas", no segundo parágrafo: "Visando aumentar o turismo da região", no terceiro: Em acréscimo, constata-se que o aterramento do mar preocupa também ambientalistas" e assim sucessivamente.

Também é inserido organizadores textuais no artigo, mantendo a conexão entre partes do texto e estabelecendo coerência em seus discursos. Utiliza-se o articulador "porém" para contrapor o argumento anterior: "Fortaleza, a Terra da Lu₹, tem belezas muito apreciadas em todo o país [...] Porém, algumas belezas se encontram comprometidas devido a projetos recentes" $\left(1^{\circ} \mathrm{P}\right)$. Nesse mesmo sentido de contraposição é inserido os articulador "entretanto" ( $\left.2^{\circ} \mathrm{P}\right)$ e "em contrapartida" (5 $5^{\circ}$ ). Também é posto articuladores no sentido de introdução ou adição de um argumento, colocado logo no início das sentenças, como podemos observar no seguinte trecho: "Em acréscimo, constata-se que o aterramento do mar preocupa também ambientalistas e pesquisadores" ( $\left.3^{\circ} \mathrm{P}\right)$. Nesse mesmo sentido temos os articuladores "Somando-se" ( $\left.3^{\circ} \mathrm{P}\right)$ / "além" (3, $4^{\circ}, 5^{\circ}$ e $\left.6^{\circ} \mathrm{P}\right) /$ "também” ( $\left.4^{\circ} \mathrm{P}\right)$ / "acresça-se que" ( $\left.6^{\circ} \mathrm{P}\right)$. Também é apresentado operadores de conformidade, quando a aluna faz referência a alguém como forma de comprovação, por exemplo, quando cita os ambientalistas, professores, a prefeitura, o poeta: “de acordo com Oriel Herrera" ( $\left.3^{\circ} \mathrm{P}\right)$ / "de acordo com o órgão" (4ㅇ P) / "como afirma o poeta Manoel de Barros” ( $\left.6^{\circ} \mathrm{P}\right)$. Ademais, estão presentes articuladores de explicação: "pois” (4 $\left.4^{\circ} \mathrm{P}\right)$, de causa: “devido a" (1 P), de conclusão: "portanto" $\left(6^{\circ} \mathrm{P}\right)$ entre outros.

No que diz respeito aos mecanismos enunciativos, que de acordo com Bronckart (2007), contribuem para regulação da coerência pragmática (interativa) do texto e para o esclarecimento dos posicionamentos enunciativos, podemos constatar com predominância a voz da aluna-produtora como principal voz articuladora. No entanto ela traz, principalmente na forma de discurso indireto e por hora em discurso direto, como citação, outras vozes que circundam e fundamentam a discussão, vozes estas as quais a aluna se aproxima, concorda, ou se distancia, se opõe (RODRIGUES, 2005). Desse modo, podemos presenciar a voz da população indiretamente, quando aluna na forma de discurso indireto comenta sobre o temor e revolta da população com relação à obra da Avenida Beira-Mar: "o que causa revolta em uma grande parcela da população" ( $\left.2^{\circ} \mathrm{P}\right)$ / "O temor da população cresce ao relembrar casos como o do Aquário do Ceará" (2a P). A voz da prefeitura também é posta, sendo, no entanto, um referente discursivo o qual a aluna se opõe: "A prefeitura de Fortaleza caracterizou o projeto como de "utilidade pública", pois, de acordo com o órgão, além de promover um aumento no turismo da cidade" (4 $\left.{ }^{\circ} \mathrm{P}\right)$. 
Em forma de concordância e comprovação de posicionamento, o texto traz as vozes de ambientalistas, pesquisadores e professores para falar sobre possíveis danos ambientais, na forma de discurso indireto e direto, como nos trechos: "como o professor do Instituto de Ciências do Mar, da Universidade Federal do Ceará, Marcelo Soares, que afirma que os impactos de grande magnitude podem causar o soterramento dos recifes de corais" ( $\left.3^{\circ} \mathrm{P}\right)$ / "Concordo, portanto, com a doutora em Ciências Marinhas, Liana Queiroz, quando ela afirma que "é imensurável a real magnitude do impacto [causado pelo aterro] em toda biodiversidade [...]” (6 $\left.6^{\circ} \mathrm{P}\right)$. E também sob o modo de discurso direto a voz de um poeta, cujo o título do seu poema inspirou o título do artigo, como já foi mencionado: "como afirma o poeta Manoel de Barros, em seu poema "Aprendimentos", ao dizer que "não tinha as certezas cientificas, mas que aprendera coisas di-menor com a natureza" [...] ( $\left.6^{\circ} \mathrm{P}\right)$. Ademais, tem a vOz da própria aluna que se mostra presente em todo o texto, mas vale destacar que sua fala se acentua mais marcadamente quando é colocada em $1^{\text {a }}$ pessoa do singular, como nos trechos seguintes: "acredito que tal avanço na urbanização" (5 $\mathrm{P})$ / Concordo, portanto, com a doutora em Ciências Marinhas" (6 P).

Ainda referente aos mecanismos enunciativos, constatamos no artigo em análise o uso de modalizações (BRONCKART, 2007, p. 330), como a modalização lógica "constata-se" $\left(3^{\circ} \mathrm{P}\right)$ que expressa um valor de verdade ao enunciado. E também uma modalização deôntica “deve-se" $\left(7^{\circ} \mathrm{P}\right)$ em que a aluna avalia a ação de preservar o litoral como necessária.

Em último lugar, é perceptível que autora do artigo de opinião faz uso de alguns recursos gráficos para dar destaque, tonicidade à algumas expressões, ou para fazer algum comentário, como o uso de parênteses e colchetes: (mar adentro) $\left(2^{\circ} \mathrm{P}\right) /$ [causado pelo aterro] $\left(6^{\circ} \mathrm{P}\right)$, utilizados como modo de explicação. E ainda o uso de aspas, colocadas algumas vezes como forma de realizar um comentário crítico ao que é dito pelo o outro, como por exemplo, na expressão "utilidade pública" ( $\left.4^{\circ} \mathrm{P}\right)$ que a produtora demarca a caracterização que a prefeitura de fortaleza deu ao projeto de requalificação, que de certa forma podemos observar um tom de crítica da aluna, e também na expressão aspeada "nobre" ( $\left.5^{\circ} \mathrm{P}\right)$, fazendo menção a região central da cidade considerada "nobre" em detrimento de outras comunidades periféricas, as aspas põem em dúvida o conceito de nobreza.

Portanto, com a análise, verificamos que a aluna-produtora desempenhou com proficiência as operações relacionadas às capacidades de ação, discursivas e linguístico-discursivas.

\section{Considerações finais}

Este estudo objetivou analisar como são mobilizadas as capacidades de linguagem (capacidades de ação, capacidades discursivas e capacidades linguístico-discursivas) para a construção de sentidos em gênero artigo de opinião. Para tanto, selecionamos para análise o artigo 
de opinião Aprendimentos Aterrados à Beira-Mar, um dos finalistas e vencedores na OLPEF, $6^{a}$ edição - 2019. Com base na proposta de análise textual do ISD buscamos compreender como o produtor do artigo analisado opera essas três capacidades para produzir, estruturar, articular o seu texto e construir sua argumentação. Dessa forma, buscou-se analisar primeiramente as operações relacionadas às capacidades de ação, em seguida, às capacidades discursivas e por último, às capacidades linguístico-discursivas.

A partir da análise, primeiramente, em relação às capacidades de ação, vimos que a aluna-produtora do artigo consegue desempenhar com proficiência a ação linguageira que é como estudante produzir um artigo de opinião que corresponda à temática "O lugar onde vivo" para OLPEF, $\sigma^{a}$ edição - 2019. Assim, obedecendo à temática, a aluna busca discutir sobre as problemáticas relacionadas ao Projeto de Requalificação da Avenida Beira-Mar de sua cidade Fortaleza- CE.

Em segundo lugar, quanto às capacidades discursivas, o artigo apresenta a planificação comum ao gênero, inserindo-se um título, uma introdução (com a polêmica e uma tese), um desenvolvimento (com argumentos e contra-argumentos) e uma conclusão (com reforço da posição). Ainda sobre a organização temática, o artigo se configura do mundo do EXPOR, desenvolvendo um discurso teórico e discurso interativo, com falas em $1^{\mathrm{a}}$ pessoa do singular e plural e predominando o tipo de sequência argumentativa.

E em terceiro lugar, referente às capacidades linguístico-discursivas, constatamos que o artigo apresenta elementos de coesão nominal, em que se faz uso de anáforas nominais e pronominais garantindo o processo de referenciação. Mantêm-se também coesão entre os sintagmas verbais, e principalmente, ao longo dos parágrafos, faz-se uso de tempos verbais no presente, que é característico do gênero. Ademais, são inseridos organizadores textuais, mantendo a conexão entre as partes do texto e estabelecendo coerência entre os discursos.

Quanto aos mecanismos enunciativos, constatamos a predominância da voz da alunaprodutora como principal voz articuladora, no entanto, ela traz principalmente na forma de discurso indireto e por hora em discurso direto, como citação, outras vozes que circundam e fundamentam a discussão, vozes estas as quais a aluna se aproxima, concorda, ou se distancia, se opõe. Fez uso de modalizações lógica e deôntica e também utilizou de recursos gráficos para dar destaque, tonicidade à algumas expressões, ou para fazer algum comentário ou crítica.

Com a análise, constatamos que a aluna-produtora do artigo de opinião desempenhou com proficiência a ação de linguagem, que por meio dos conhecimentos relacionados às capacidades de ação, capacidades discursivas e linguístico-discursivas do gênero textual, ela 
conseguiu atender a proposta de produção desse gênero, conseguindo apresentar um artigo opinativo, argumentativo de forma coesa e coerente, o que certamente contribuiu para essa produção ser uma das finalistas e vencedoras em um concurso tão relevante.

Portanto, acreditamos que este estudo contribui para que a proposta de produção e análise textual a partir das capacidades de linguagem, com base no ISD, seja mais difundida, contribuindo com outras pesquisas que se interessam por produção e análise textual, especialmente de artigos de opinião, seja no contexto da OLPEF ou em outros contextos.

\title{
LANGUAGE CAPACITIES IN GENDER OPINION ARTICLE: A TEXTUAL ANALYSIS IN THE LIGHT OF SOCIODISCURSIVE INTERACIONISM
}

\begin{abstract}
In this study, we aim to analyze how language capacities (action capacities, discursive capacities and linguistic-discursive capacities) are mobilized for the construction of meanings in the opinion article genre. We selected to analyze the article "Aprendimentos Aterrados à Beira-Mar", one of the winners at the Portuguese Language Olympiad "Escrevendo o Futuro", 6th edition - 2019". We aim to understand how the article's author work with these capacities to structure his text and build his argument. For this, we are based on the theoretical framework of Sociodiscursive Interactionism, highlighting the studies by Bronckart (2007) and Dolz and Schneuwly (2004), who defend the production and textual analysis based on language skills, in Machado (2005), which helps to understand this theory and to understand the opinion article genre, we rely on Castellani and Barros (2018), Rodrigues (2005) and Uber (2008). As a result, we verified that the producer of the analyzed article proficiently performs the action of language, demonstrating awareness of the situation and purpose of communication. It presents knowledge regarding the structure of the opinion article genre, presenting a controversial situation, defending a thesis with arguments and counter-arguments, using theoretical discourse and argumentative sequences. In addition it presents enunciative and textualization mechanisms that contribute to textual cohesion and coherence.
\end{abstract}

KEYWORDS: Sociodiscursive Interactionism; Language capabilities; Gender opinion article; Portuguese Language Olympiad "Escrevendo o Futuro".

\section{REFERÊNCIAS}

BRONCKART, Jean-Paul. Atividade de linguagem, textos e discurso: por um interacionismo sociodiscursivo. Tradução de Anna Rachel Machado e Péricles Cunha. 2 ed. São Paulo: EDUC, 2007.

. Interacionismo Sociodiscursivo: uma entrevista com Jean-Paul Bronckart. Revista Virtual de Estudos da Linguagem - ReVEL. Vol. 4, n. 6, março de 2006.Tradução de Cassiano Ricardo Haag e Gabriel de Ávila Othero.

CASTELLANI, Rithielle Aparecida; BARROS, Eliana Merlin Deganutti de. Modelo teórico/didático do gênero artigo de opinião: ferramentas para análise do gênero. Entrepalavras, Fortaleza, v. 8, n. 2, p. 196-214, maio/ago. 2018.

DOLZ, Joaquim; SCHNEUWLY, Bernard; Gêneros e progressão em expressão oral e escrita: elementos para reflexões sobre uma experiência Suíça. In: e escritos na escola. Campinas: Mercado das Letras, 2004. p. 95-128. - (Org.). Gêneros orais

LIMA, Paulo da Silva. A reescrita de textos na escola: trabalhando com gêneros e sequências didáticas. Tese (Doutorado em Letras). Universidade Presbiteriana Mackenzie, Câmpus de Higienópolis, 2014. 
MACHADO, Anna Rachel. A perspectiva interacionista sociodiscursiva de Bronckart. In: MEURER, J. L.; BONINE, A. MOTTA-ROTH, D (Orgs.). Gêneros, teorias, métodos, debates. São Paulo: Parábola Editorial, 2005.

OLIMPÍADA de Língua Portuguesa Escrevendo o Futuro. O lugar onde Vivo (Coletânea de textos finalistas). 6a. ed. São Paulo: CEMPEC, 2019.

Disponível em: < https://www.escrevendoofuturo.org.br/arquivos/9161/textos-finalistas2019.pdf>. Acesso em: 20 dez 2019.

PRESTES, Maria Luci de Mesquita. A pesquisa e a construção do conbecimento cientifico: do planejamento aos textos, da escola à academia. 4 ed. São Paulo: Rêspel, 2012.

RODRIGUES, Rosângela Hammes Rodrigues. Os gêneros do discurso na perspectiva dialógica da linguagem: a abordagem de Bakhtin. In: MEURER, J. L.; BONINE, A. MOTTAROTH, D (Orgs.). Gêneros, teorias, métodos, debates. São Paulo: Parábola Editorial, 2005.

UBER, Terezinha de Jesus Bauer. Artigo de opinião: Estudos sobre um gênero discursivo. Artigo apresentado em conclusão ao Programa de Desenvolvimento Educacional da Secretaria de Estado da Educação do Paraná - PDE -, Maringá, 2008.

Recebido em: 22/03/2021.

Aprovado em: 02/06/2021. 